\title{
The Effect of Flipped Classroom Model on Students' Classroom Engagement in Teaching English
}

\section{Burak Ayçiçek}

Ph.D. Student, corresponding author, Mersin University, Department of Educational Sciences, Mersin, Turkey, aycicekburak@gmail.com

\section{Tuğba Yanpar Yelken}

Prof., Mersin University, Department of Educational Sciences, Mersin, Turkey, tyanpar@gmail.com

In the current study, the aim is to determine the effect of flipped classroom model on students' classroom engagement in teaching English. This research was conducted within the English course for four weeks period in the Spring term in 2016-2017 school year in a secondary school in the city of Hatay. In the study, pretest/post-test quasi-experimental design with control group was applied. The experimental group was lectured with flipped classroom model whereas the courses were carried out based on the current curriculum in the control group. In the current study, descriptive statistics, Mann Whitney U Test and Wilcoxon Sign Test were used in the analysis of the quantitative data. It was concluded that there is a significant difference between the pre-test and post-test scores of the experimental group whearas there is no significant difference between the pre-test and post-test scores of the control group. Finally, teachers can be suggested to use flipped classroom model to enhance classroom engagement.

Keywords: flipped classroom model, classroom engagement, secondary school students, teaching, teaching English, English course

\section{INTRODUCTION}

The personal needs of individuals have changed through the influence of external factors such as rapidly increasing population and developing technology. Traditional instruction methods have become inadequate in meeting different learning demands. The reason of this is that students do not feel themselves comfortable and learning environment is not appropriate for them in the traditional instruction system where the teacher is in the center of the learning process, (Cooper, 2001). Students are passive learners in traditional instruction systems, which causes students to be inefficient during learning process.

Citation: Ayçiçek, B., \& Yanpar Yelken, T. (2018). The Effect of Flipped Classroom Model on Students' Classroom Engagement in Teaching English. International Journal of Instruction, 11(2), 385-398. https://doi.org/10.12973/iji.2018.11226a 
More efficient education approaches must be applied in order to compensate these demands. In this regard, innovative learning approaches assisted by technological opportunities can be used. Indeed, giving more space and time to technology in learning process will provide students with contemporary skills and improve education system by providing a real education reform (Overmyer, 2014). Creating technology-based training environments in the education system will bring innovation to educational settings.

One of the most effective ideas to carry out the reforms required by the age of education is flipped classroom model. The flipped classroom model, which is often heard in recent years, is known as a new pedagogical approach in which traditional instruction is reversed. This model focuses on group learning rather than individual learning. In flipped classrooms, teacher guides the concepts effectively by creating a dynamic and interactive learning environment (Flipped Learning Network-FLN, 2014). According to Bergmann and Sams (2012), the main purpose of the flipped classroom model is to use face to face time more effectively in the learning process.

There are many definitions related to flipped classroom model. According to Bishop and Verleger (2013) flipped classroom is a student-centred learning method consisting of two parts with interactive learning activities during lesson and individual teaching based on computer out of lesson. Bergmann \& Sams (2012) explained traditional flipped classroom model as "what is done at school done at home, homework done at home completed in class". Basic information is provided by the resources and materials shared by teacher before class. Some activities such as problem solving, discussion, brainstorming are performed during class time and teacher has the role of guide in this process.

In flipped classroom approach, teachers prepare some videos about the subjects that they are going to teach. Students are expected to watch the videos before coming to the classes. The lesson starts with short questions and answers. If there are points in lecture that are not understood, they are explained. During class time, students are given opportunity to learn by discussing. However in traditional approach teaching of subject takes the most of course time (Bergmann \& Sams, 2012).

The flipped classromm model has many advantages for both individual learning process and in-class learning process. The advantages that Fulton (2012) expressed are; students can access lecture videos whenever and wherever they want and it provides students to learn at their own speed. The students that are educated with this approach are encouraged to think both within and out of class (Kellinger, 2012). The model includes both active learning and the advantages of individual learning (Bishop and Verleger, 2013). In addition to all these advantages, Herreid and Schiller (2013) reported that flipped classroom approach provides students more time to make inventive researches.

Despite the advantages of the flipped classroom model, there are some disadvantages. Bristol (2014) expressed the difficulties that may occur when the students do not watch the videos before coming to the class. According to Kordyban and Kinash (2013), teachers may have difficulty in understading whether the students do their responsibilities out of class or not. The biggest disadvantage for teachers is not 
preparing or broadcasting lecture videos but preparing in class activities and integrating them to flipped classroom approach (Lafee, 2013).

The flipped classroom model is developed pedagogically by using educational technologies to create the most efficient time for class activities. In this approach students can use technological equipments, develop their abilities, create interactive discussion conditions, discover different learning methods with different learning acitivities. According to Millard (2012), flipped classroom approach increases students' active engagement in the class.

Classroom engagement, which is one of the important factors to create an effective learning environment, is considered as an indicator of student achievement (Handelsman et al., 2005). In the simplest terms, classroom engagement can be defined as active involvement of the student for learning activities (Skinner et al., 2009). Chapman (2003) defines classroom engagement as the willingness of the student to engage in daily school activities, such as continuing to school, doing homework, and listening to teacher in class.

The low level of classroom engagemant leads to negative effects on course performance and learning process (Wang et al., 2014). In this respect, Fletcher (2007) points out that student engagement is the result of successful classroom teaching and school development activities and that it is an increasingly important concept on that sense.

Coates (2007) emphasize the importance of active and collaborative learning, academic activities, effective communication with the teacher and educational experiences within the scope of classroom engagement.

Students' classroom engagement levels are evaluated by affective engagement, cognitive engagement and behavioral engagement. (Wang, Bergin and Bergin, 2014). In the classroom, affective engagement refers to the positive feelings of students such as interest, excitement and amusement. Cognitive engagement refers to the processes such as meaningful-processing, strategy use, concentration and metacognition. Behavioral engagement refers to the observable behaviors such as asking questions, being active in team-works and completing tasks without delay (Skinner, Kindermann \& Furrer, 2009).

It is anticipated that this study will contribute to teacher training institutions, teachers and researchers working on the related subjects. This research was conducted within the English course for 4 weeks period in the Spring term in 2016-2017school year in a secondary school with seventh grade students in the city of Hatay.

\section{Purpose}

The purpose of the current study is to determine the effect of flipped classroom model on students' classroom engagement in teaching English. To this end, answer to the following question was sought:

- Is there a significant difference between classroom engagement levels of the students in the experimental group who is lectured with flipped classroom model 
and those in the control group whose courses are carried out based on the current curriculum?

\section{METHOD}

\section{Research Design}

In the current study, the effect of flipped classroom models on students' classroom engagement within the English course was examined in a quasi-experimental pretestposttest design. Quasi-experimental is used to replace the design of real experiments when a random distribution for the respondents' selection process cannot be done by the researchers (Chua, 2006).

\section{Study Groups}

Since the study is of experimental type, neither a population nor a sample has been assigned. The subjects of the groups have been seventh grade students in a secondary school in the city of Hatay. One of the classes was randomly assigned to the control group whereas the other class was randomly assigned to the experimental group. The total participant number for the study was 40 . Both experimental and control groups included 20 participants.

\section{Data Collection Instruments}

In the study, "Classroom Engagement Inventory" was used to collect data. "Classroom Engagement Inventory" was developed by Wang, Bergin and Bergin (2014) and adapted to Turkish by Sever (2014). In the original form, the inventory consisted of 24 items, but after the elimination of one item in the adaptation process, there remained 23 items. The inventory consisted of five sub-factors; "Cognitive Engagement", "Affective Engagement", "Behavioural Engagement -Compliance, "Behavioral EngagementEffortful Classroom Participation", and "Disengagement".

The reliability of the scale has been recalculated for this study and the Cronbach alpha coefficient of reliability has been found as .93 and this coefficient has been thought adequate for an attitude scale. The Cronbach alpha is used to determine the reliability of the research instrument. According to Hair et al. (2010), the Cronbach alpha value of more than .70 is acceptable and sufficient. The value of reliability coefficient in this study is .93 , suggesting that the research instrument is reliable.

"Classroom Engagement Inventory" was devoloped for high school students. In this study, the inventory was applied to secondary school students. So, confirmatory factor analysis was carried out again. Inventory's confirmatory factor analysis adaptation indices results can be summarized as follows: RMSEA=0.056; AGFI=0.955; $\mathrm{RMR}=0.066 ; \mathrm{GFI}=0.951$.

The scale which is composed of 23 items, 20 of which positive and 3 of which negative is Likert-type. The scale has been given to the experimental and control groups before and after the application. 5-point grading scale whose answers varies from "always" to "never" is used in the scale. The method of scoring for positive items is 'always:5, 
generally:4, sometimes:3, rarely:2, never:1' while the method for negative items is 'always:1, generally:2, sometimes:3, rarely:4, never:5'. The total score for each student is the sum of marked choices. The students have been assumed to reflect their real opinions while replying to the scale. It is supposed that uncontrolled variables equally affect both groups.

\section{Data Analysis}

The study aimed to determine the effect of flipped classroom model on students' classroom engagement in teaching English.

The data collected from the study were thought to be analyzed using independent samples t-test. An independent samples t-test is a statistical tool used for comparing the mean score of the two different groups (Tabachnick \& Fidell, 2001). However, one of the prerequisites for the use of parametric tests is the assumption of the normal distribution of the data and another is the assumption of large sample (at least 30 people in groups) (Büyüköztürk, 2013; Green \& Salkind, 2008; Kalayc1, 2005; Özdamar, 2013). Since the number of individuals in the groups is under 30, there is no need to use Kolmogorov-Smirnov Normal Distribution Test to test whether the data exhibit normal distribution, so it is appropriate to use non-parametric Mann Whitney U Test and Wilcoxon Sign Test.

\section{Experimental Process}

The experiment covered a period of four weeks and was applied only to the experimental group using flipped classroom model as their teaching approach. The control group, on the other hand, was taught using traditional teaching approach. In the beginning of the experiment, pretest was administered to the students of both experimental and control groups. After the four weeks experiment, the post-test was administered to the experimental and control groups.

The scope, goals and achievements of the course have been taken into consideration during the design of the activities in the four-week lesson plan. Effective tools and environments in the related literature have been identified to make the experiment more effective and efficient. Course contents have been developed with the help of these environments and tools.

The tool used in the study is screencast-matic software which was used in the process of creating video lectures for the students in the experimental group. This software allows to record the user's screen and the user's voice in various video formats. This software is preferred because it allows user to make various edits and attachments within features such as adding emphasis, adding and saving sounds, making videos interactive by adding questions and easy sharing.

The instructor has prepared video lectures by using the software mentioned above. All of the video lectures in this study lasted for approximately 18-20 minutes. The duration of video lectures is shortened based on the recommendations given in the literature, because as Wan (2014) and Sarawagi (2014) state, short videos (not more than 15 minutes) are helpful to guarantee students' understanding. 
Each video lecture involved the content stated in the curriculum and the content was presented to the students with multiple questions and open ended questions which were embedded on the videos via Edpuzzle, an educational platform where video lectures are made available to students by using class code and password.

Video lectures are only allowed to be accessed by the experimental group. The videos recorded via Screencast-matic are uploaded to the Edpuzzle platform. Edpuzzle provides a report for instructor about whether students has watched videos, students' answers to the questions and the number of times students have watched videos. The sample question screen shared by Edpuzzle is presented in Figure 1.
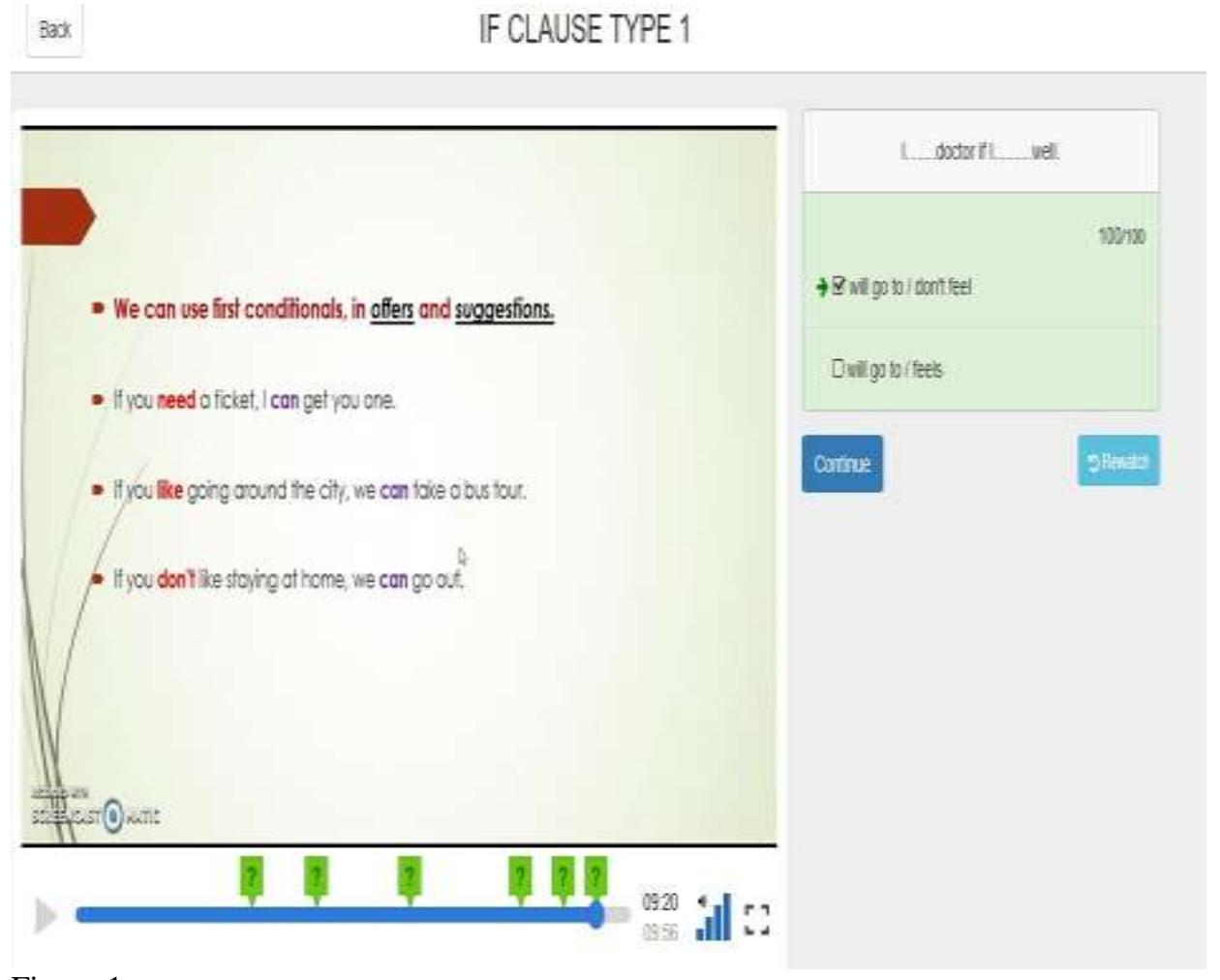

Figure 1

Edpuzzle sample question screenshot

\section{FINDINGS}

In this section, findings obtained from the statistical analysis of the data collected about the effect of flipped classroom model on students' classroom engagement in teaching English are presented.

Descriptive statistics for the pretest and posttest scores obtained by the experimental and control groups are given in Table 1. 
Table 1

Pretest and posttest statistics of the experimental and control groups

Pre-test Post-test

\begin{tabular}{|c|c|c|c|c|c|c|c|c|c|c|c|}
\hline Group & $\begin{array}{l}\text { Descriptive } \\
\text { statistics }\end{array}$ & 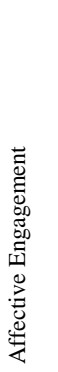 & 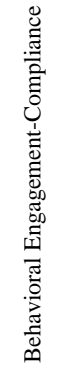 & 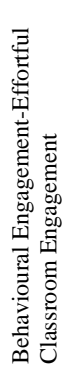 & 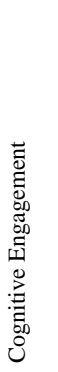 & 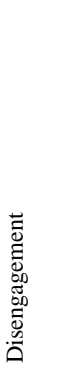 & 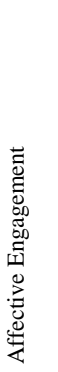 & 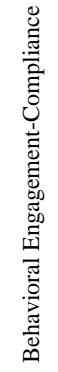 & 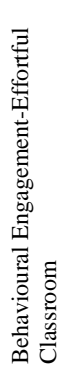 & 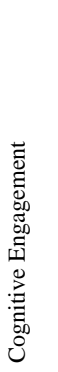 & 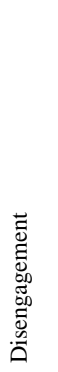 \\
\hline \multirow{10}{*}{$\begin{array}{l}\text { Experimantal } \\
\text { Group }\end{array}$} & $\mathrm{N}$ & 20 & 20 & 20 & 20 & 20 & 20 & 20 & 20 & 20 & 20 \\
\hline & Arithmetic Mean & 17,5 & 11,9 & 9,0 & 21,3 & 9,5 & 22,8 & 15,3 & 11,9 & 27,6 & 6,0 \\
\hline & Median & 15,5 & 10,5 & 8 & 19,5 & 10 & 26 & 18 & 13 & 32 & 4 \\
\hline & Mode & 29 & 7 & 6 & 14 & 3 & 26 & 18 & 13 & 33 & 4 \\
\hline & Standard Deviation & 7,6 & 4,9 & 3,6 & 8,7 & 4,7 & 7,0 & 5,1 & 3,8 & 8,8 & 4,1 \\
\hline & Skew & 0,5 & 0,5 & 0,4 & 0,6 & $-0,5$ & $-1,3$ & $-1,3$ & $-1,3$ & $-1,4$ & 1,3 \\
\hline & Kurtosis & $-1,3$ & $-1,3$ & $-1,2$ & $-1,3$ & $-1,4$ & 0,3 & 0,6 & 0,3 & 0,6 & 0,4 \\
\hline & Ranj & 22 & 14 & 11 & 24 & 12 & 21 & 16 & 11 & 27 & 12 \\
\hline & Minimum Score & 7 & 6 & 4 & 11 & 3 & 8 & 4 & 4 & 8 & 3 \\
\hline & Maximum Score & 29 & 20 & 15 & 35 & 15 & 29 & 20 & 15 & 35 & 15 \\
\hline \multirow{10}{*}{ Control Group- } & $\mathrm{N}$ & 20 & 20 & 20 & 20 & 20 & 20 & 20 & 20 & 20 & 20 \\
\hline & Arithmetic Mean & 17,3 & 11,7 & 9,2 & 21,2 & 9,6 & 17,1 & 11,5 & 9,1 & 21,4 & 9,6 \\
\hline & Median & 16,5 & 10,5 & 9 & 20,5 & 9,5 & 16,5 & 10,5 & 9 & 21 & 9,5 \\
\hline & Mode & 9 & 7 & 6 & 13 & 9 & 9 & 7 & 6 & 13 & 13 \\
\hline & Standard Deviation & 7,6 & 4,8 & 3,2 & 8,3 & 3,9 & 7,2 & 4,9 & 3,4 & 8,5 & 3,9 \\
\hline & Skew & 0,4 & 0,5 & 0,4 & 0,3 & $-0,2$ & 0,4 & 0,4 & 0,3 & 0,3 & $-0,3$ \\
\hline & Kurtosis & $-1,4$ & $-1,3$ & $-1,5$ & $-1,5$ & $-1,4$ & $-1,4$ & $-1,4$ & $-1,6$ & $-1,6$ & $-1,4$ \\
\hline & Ranj & 21 & 14 & 9 & 22 & 11 & 19 & 14 & 9 & 22 & 11 \\
\hline & Minimum Score & 8 & 6 & 5 & 11 & 4 & 9 & 5 & 5 & 11 & 4 \\
\hline & Maximum Score & 29 & 20 & 14 & 33 & 15 & 28 & 19 & 14 & 33 & 15 \\
\hline
\end{tabular}

In the classroom engagement inventory, the highest scores that can be taken from the "affective engagement" dimension is 30 ; from the "behavioral engagement -compliance" dimension is 20; from the "behavioral engagement-class" dimension is 15; from the "cognitive engagement"is 35; from the "disengagement" dimension is 15.

When the scores given in Table 1 are examined, it is seen that the classrom engagement levels of the experimental and control groups are at medium level in terms of pre-test scores. In post-test scores, the level of classroom engagement of the control group is almost similar, but the level of classroom engagement of the experimeantal group has increased. The skewness and kurtosis values of the two groups in both pre-test and posttest are more than \pm 1 . This shows that the scores do not have a normal distribution.

The results of the statistical analysis related to the pre-test scores of the experimental and control groups are given in Table 2. 
Table 2

Comparison of the pre-test scores of the experimental and control groups (Mann Whitney U Test)

\begin{tabular}{|c|c|c|c|c|c|c|}
\hline Sub-Dimension & Group & $\mathrm{N}$ & $\begin{array}{l}\text { Mean } \\
\text { Rank }\end{array}$ & Rank Sum & $\mathrm{U}$ & $\mathrm{p}$ \\
\hline \multirow[t]{2}{*}{ Affective Engagement } & Experimental & 20 & 20,80 & 416,00 & \multirow{2}{*}{194,000} & \multirow{2}{*}{0,871} \\
\hline & Control & 20 & 20,20 & 404,00 & & \\
\hline \multirow{2}{*}{$\begin{array}{l}\text { Behavioral Engagement- } \\
\text { Compliance }\end{array}$} & Experimental & 20 & 20,93 & 418,50 & \multirow{2}{*}{191,500} & \multirow{2}{*}{0,817} \\
\hline & Control & 20 & 20,08 & 401,50 & & \\
\hline \multirow{2}{*}{$\begin{array}{l}\text { Behavioural Engagement- } \\
\text { Effortful Classroom } \\
\text { Engagement }\end{array}$} & Experimental & 20 & 20,30 & 406,00 & \multirow[b]{2}{*}{196,000} & \multirow[b]{2}{*}{0,913} \\
\hline & Control & 20 & 20,70 & 414,00 & & \\
\hline \multirow[t]{2}{*}{ Cognitive Engagement } & Experimental & 20 & 20,93 & 418,50 & \multirow{2}{*}{191,500} & \multirow{2}{*}{0,817} \\
\hline & Control & 20 & 20,08 & 401,50 & & \\
\hline \multirow{2}{*}{ Disengagement } & Experimental & 20 & 20,60 & 412,00 & \multirow{2}{*}{198,000} & \multirow{2}{*}{0,956} \\
\hline & Control & 20 & 20,40 & 408,00 & & \\
\hline
\end{tabular}

According to the data given in Table 2, it is seen that there is no significant difference in five sub-dimensions ( $\mathrm{p}>.05$ ). This is an expected result in experimental designs. In the light of the data presented in Table 2, it was verified that the experimental and control groups were equal before the experimental process in terms of classroom engagement levels.

The results of the statistical analysis related to post-test scores of the experimental and control groups are given in Table 3 .

Table 3

Comparison of the post-test scores of the experimental and control groups (Mann Whitney U Test)

\begin{tabular}{|c|c|c|c|c|c|c|}
\hline Sub-Dimension & Group & $\mathrm{N}$ & $\begin{array}{l}\text { Mean } \\
\text { Rank }\end{array}$ & $\begin{array}{l}\text { Rank } \\
\text { Sum }\end{array}$ & $\mathrm{U}$ & $\mathrm{p}$ \\
\hline \multirow{2}{*}{ Affective Engagement } & Experimental & 20 & 24,55 & 491,00 & \multirow{2}{*}{119,000} & \multirow{2}{*}{0,028} \\
\hline & Control & 20 & 16,45 & 329,00 & & \\
\hline \multirow{2}{*}{$\begin{array}{l}\text { Behavioral Engagement- } \\
\text { Compliance }\end{array}$} & Experimental & 20 & 24,55 & 491,00 & \multirow{2}{*}{119,000} & \multirow{2}{*}{0,027} \\
\hline & Control & 20 & 16,45 & 329,00 & & \\
\hline \multirow{2}{*}{$\begin{array}{l}\text { Behavioural Engagement- } \\
\text { Effortful Classroom Engagement }\end{array}$} & Experimental & 20 & 24,80 & 496,00 & \multirow{2}{*}{114,000} & \multirow{2}{*}{0,019} \\
\hline & Control & 20 & 16,20 & 324,00 & & \\
\hline \multirow[t]{2}{*}{ Cognitive Engagement } & Experimental & 20 & 24,40 & 488,00 & \multirow{2}{*}{122,000} & \multirow{2}{*}{0,034} \\
\hline & Control & 20 & 16,60 & 332,00 & & \\
\hline \multirow[t]{2}{*}{ Disengagement } & Experimental & 20 & 15,05 & 301,00 & \multirow{2}{*}{91,000} & \multirow{2}{*}{0,003} \\
\hline & Control & 20 & 25,95 & 519,00 & & \\
\hline
\end{tabular}

As seen in Table 3, it is clear that there is a significant difference in five sub-dimensions ( $>$.05). In Table 3, the post-tests scores of the experimantal group are higher than those of the control group. In this regard, it can be said that the application of the flipped classroom model increases students' classroom engagement levels.

The results of the statistical analysis related to the comparison of the pretest and posttest scores of the experimental group are given in Table 4 . 
Table 4

Comparison of the pre-test and post-test scores of the experimental group (Wilcoxon Sign Test)

\begin{tabular}{|c|c|c|c|c|c|c|}
\hline Sub-Dimension & Posttest-Pretest & $\mathrm{N}$ & Mean Rank & Rank Sum & $\mathrm{z}$ & $\mathrm{p}$ \\
\hline \multirow{2}{*}{$\begin{array}{l}\text { Affective } \\
\text { Engagement }\end{array}$} & $\begin{array}{l}\text { Negative } \\
\text { Sequence }\end{array}$ & 3 & 2,00 & 6,00 & \multirow{2}{*}{$-2,923$} & \multirow{2}{*}{0,003} \\
\hline & $\begin{array}{l}\text { Positive } \\
\text { Sequence }\end{array}$ & 11 & 9,00 & 99,00 & & \\
\hline \multirow{2}{*}{$\begin{array}{l}\text { Behavioral } \\
\text { Engagement- } \\
\text { Compliance }\end{array}$} & $\begin{array}{l}\text { Negative } \\
\text { Sequence }\end{array}$ & 3 & 3,33 & 10,00 & \multirow{2}{*}{$-2,849$} & \multirow{2}{*}{0,004} \\
\hline & $\begin{array}{l}\text { Positive } \\
\text { Sequence }\end{array}$ & 12 & 9,17 & 110,00 & & \\
\hline \multirow{2}{*}{$\begin{array}{l}\text { Behavioural } \\
\text { Engagement- } \\
\text { Effortful Classroom } \\
\text { Engagement }\end{array}$} & $\begin{array}{l}\text { Negative } \\
\text { Sequence }\end{array}$ & 2 & 1,50 & 3,00 & \multirow{2}{*}{$-2,978$} & \multirow{2}{*}{0,003} \\
\hline & $\begin{array}{l}\text { Positive } \\
\text { Sequence }\end{array}$ & 11 & 8,00 & 88,00 & & \\
\hline \multirow{2}{*}{$\begin{array}{l}\text { Cognitive } \\
\text { Engagement }\end{array}$} & $\begin{array}{l}\text { Negative } \\
\text { Sequence }\end{array}$ & 4 & 2,50 & 10,00 & \multirow{2}{*}{$-2,840$} & \multirow{2}{*}{0,003} \\
\hline & $\begin{array}{l}\text { Positive } \\
\text { Sequence }\end{array}$ & 11 & 10,00 & 110,00 & & \\
\hline \multirow[t]{2}{*}{ Disengagement } & $\begin{array}{l}\text { Negative } \\
\text { Sequence }\end{array}$ & 11 & 10,00 & 110,00 & \multirow{2}{*}{$-2,867$} & \multirow{2}{*}{0,004} \\
\hline & $\begin{array}{l}\text { Positive } \\
\text { Sequence }\end{array}$ & 4 & 2,50 & 10,00 & & \\
\hline
\end{tabular}

* Based on negative sequence basis

On the basis of the data presented in Table 4, it is clear that the post-test scores of the experimental group were found to be significantly higher than pre-test scores $(p<.05)$. This result proves that flipped classroom model increases students' classroom engagement levels.

The results of the statistical analysis related to the comparison of the pretest and posttest scores of the control group are given in Table 5. 
Table 5

Comparison of the pre-test and post-test scores of the control group (Wilcoxon Sign Test)

\begin{tabular}{|c|c|c|c|c|c|c|}
\hline Sub-dimension & Posttest-Pretest & $\mathrm{N}$ & Mean Rank & Rank Sum & $\mathrm{Z}$ & $\mathrm{p}$ \\
\hline \multirow{2}{*}{$\begin{array}{l}\text { Affective } \\
\text { Engagement }\end{array}$} & $\begin{array}{l}\text { Negative } \\
\text { Sequence }\end{array}$ & 6 & 5,00 & 30,00 & \multirow[t]{2}{*}{$-1,000$} & \multirow[t]{2}{*}{0,317} \\
\hline & Positive Sequence & 3 & 5,00 & 15,00 & & \\
\hline \multirow{2}{*}{$\begin{array}{l}\text { Behavioral } \\
\text { Engagement- } \\
\text { Compliance } \\
\end{array}$} & $\begin{array}{l}\text { Negative } \\
\text { Sequence }\end{array}$ & 7 & 5,00 & 35,00 & \multirow[t]{2}{*}{$-1,667$} & \multirow[t]{2}{*}{0,096} \\
\hline & Positive Sequence & 2 & 5,00 & 10,00 & & \\
\hline \multirow{2}{*}{$\begin{array}{l}\text { Behavioural } \\
\text { Engagement- } \\
\text { Effortful Classroom } \\
\text { Engagement }\end{array}$} & $\begin{array}{l}\text { Negative } \\
\text { Sequence }\end{array}$ & 4 & 3,50 & 14,00 & \multirow{2}{*}{$-0,816$} & \multirow{2}{*}{0,414} \\
\hline & Positive Sequence & 2 & 3,50 & 7,00 & & \\
\hline \multirow[t]{2}{*}{$\begin{array}{l}\text { Cognitive } \\
\text { Engagement }\end{array}$} & $\begin{array}{l}\text { Negative } \\
\text { Sequence }\end{array}$ & 2 & 6,75 & 13,50 & \multirow[t]{2}{*}{$-1,155$} & \multirow[t]{2}{*}{0,248} \\
\hline & Positive Sequence & 7 & 4,50 & 31,50 & & \\
\hline \multirow[t]{2}{*}{ Disengagement } & $\begin{array}{l}\text { Negative } \\
\text { Sequence }\end{array}$ & 1 & 1,00 & 1,00 & \multirow{2}{*}{$-1,000$} & \multirow{2}{*}{0,317} \\
\hline & Positive Sequence & 0 & 00 & ,00 & & \\
\hline
\end{tabular}

* Based on negative sequence basis

The data given in Table 5 show that there is no significant difference between the pretest and post-test scores of the control group in the five sub-dimensions ( $p>.05)$. In the light of the data given in Table 5, it can be argued that students' classroom engagement levels did not change during the experimental process.

\section{DISCUSSION AND CONCLUSION}

In the current study, it was observed that there was no significant difference between the experimental and control groups according to pre-test results in students' classroom engagement levels. However, when examining the post-test scores, it was seen that the classrom engagement levels of the experimental group was higher than those of the control group. This may be due to the fact that in the flipped classroom model, students can get oppurtunities to make one to one interaction with teachers and friends and to study the course content at different times independent from time and space.

The model has some advantages for students in terms of ensuring that students are prepared for the lesson, making the course fun and productive, providing teacher guidance and teamwork, and motivating students by creating a competitive atmosphere within the classroom. In addition, it can be said that the technology which is integrated into the flipped classrooms supports individual learning, which helps increase the success of students. As a result of these advantages, it is expected that classroom engagement level of the students will be positively influenced by the application of this model. 
The flipped classroom model enables students to participate more actively in classes. Active learning activities in the class within the model may positively affect the classroom engagement levels of the students. This may be due to the fact that the students perform the activities in class with the guidance of the teacher and that the teacher gives immediate feedback. In such educational settings, student can get the chance of developing their high-level thinking skills. According to Bergmann \& Waddell (2012), in flipped classroom approach the students can find opportunities to discuss with their teachers which is not a possible situation in traditional. Also, the students are encouraged to think both within and out of the class (Kellinger, 2012). Such various teaching strategies help students to be active learners in the classroom.

The point is that flipped classes provide active learning environment which holds students at the centre of education process. This is supported by studies showing that the flipped classroom model provides active engagement of students in the classroom (Enfield, 2013; Hung, 2015). Similarly, in the study conducted by Hurley (2014) it is stated that flipped classes provide active engagement for class activities. In-class activities probably make students have a positive attitude towards the model. Through different kinds of activities, students gain learning experiences.

The studies in the literature related to the flipped classroom model are compared with the traditional learning method. In the study of Boyraz (2014), the flipped classroom model had a positive effect on academic achievement in comparison with traditional instruction methods in teaching English. In the study of Hung (2015), it is concluded that the effect of the flipped classroom model in teaching English is more effective in terms of getting better learning outcomes for students. In addition, Baepler, Walker and Driessen (2014) emphasize the fact that flipped classroom models provide students more effective learning environments due to the flexible classroom structure of flipped classes.

Given that the increased level of classroom engagement will bring academic success, many studies have been found in the literature which prove that the model increase achievement in various branches. Bösner et al. (2015) observed a significant increase in the academic achievement of the study group to which the model was applied and this was attributed to the fact that the flipped classroom model was a process enabling interactive and application-based learning. Yestrebsky (2015) aims to investigate the effect of flipped clasroom on large sample population and he achieved higher achievement scores compared to traditional instruction models. Similarly, the study conducted by Akgün and Atıc1 (2017) showed that flipped classes increased the academic achievement of students. It can be said that student's engagement in the learning process allows students to develop skills such as analytical thinking, problemsolving, creative thinking and meta-cognitive for their academic achievement.

As a result, it is concluded that flipped classes create flexible learning environments by providing active learning activities and allowing students to assume individual learning responsibilities. Thus, it can be said that flipped classroom model is effective in creating an efficient learning process. The model enables learners to acquire new skills and to cause radical changes in their learning habits. 
In light of these findings of the current study, following suggestions can be made:

- Teachers should be informed about the model and motivated to use technology.

- Seminars and workshops related to the model can be organized in order to make the model more widespread.

- It is necessary to plan technical capacity of learning environment well in order to make the process in the class more efficient.

- If students in the study have problems about accessing internet, course contents should be provided to them by equipments such as CD, DVD, portable memory, etc.

- In future studies, the effect of the model should be studied in other education levels and courses.

- Future studies can also include opinions of students and parents about the model.

\section{REFERENCES}

Akgün, M., \& Atıcı B. (2017). The Effect of Flipped Classroom on Learners' Academic Achievements and Views. Kastamonu Education Journal, 25(1), 329-344.

Baepler, P., Walker, J. D., \& Driessen, M. (2014). It is not about seat time: Blending, flipping, and efficiency in active learning classrooms. Computers \& Education, 78, 227236.

Bergmann, J., \& Waddell, D. (2012). To flip or not to flip?. Learning and Leading With Technology, 39 (8).

Bergmann, J., \& Sams, A. (2012). Flip your classroom: Reach every student in every class every day. Washington: International Society for Technology in Education.

Bishop, J. L., \& Verleger, M. A. (2013). The flipped classroom: A survey of the research. In ASEE National Conference Proceedings, Atlanta, GA.

Boyraz, S. (2014). Evaluating Flipped Classroom/Education Method in English Teaching. Unpublished Master's Thesis. Afyon: Afyon Kocatepe University.

Bösner, S., Pickert, J., \& Stibane, T. (2015). Teaching differential diagnosis in primary care using an inverted classroom approach: student satisfaction and gain in skills and knowledge. BMC medical education, 15(1), 1.

Bristol, T. J. (2014). Educate, excite, engage. Teaching and Learning in Nursing, 9, 4346.

Büyüköztürk, Ş. (2013). Sosyal bilimler için veri analizi el kitabı. Ankara: Pegem

Chapman, E. (2003). Alternative approaches to assessing student engagement rates. Practical Assessment, Research \& Evaluation, 8 (13).

Chua, Y. P. (2006). Research Methodology. Serdang: McGraw Hill (Malaysia) 
Coates, H. (2007). A model of online and general campus-based student. Assesment \& Evaluation in Higher Education, 32(2), 121-141.

Cooper, H., \& Valentine, J. C. (2001). Using research to answer practical questions about homework. Educational Psychologist, 36 (3), 143-153.

Enfield, J. (2013). Looking at the impact of the flipped classroom model of instruction on undergraduate multimedia students at CSUN. Techtrends: Linking Research \& Practice To Improve Learning, 57(6), 14-27.

Fletcher, A. (2007). Defining student engagement: A literature review. Retrieved March, 10, 2017 from http://soundout.org/defining-student-engagement-a-literature-review/.

Flipped Learning Network (FLN). (2014). The four pillars of FLIPTM. Retrieved March, 08, 2017, from www. flippedlearning. org/ definition.

Fulton, K. (2012). Upside down and inside out: Flip your classroom to improve student learning. Learning \& Leading with Technology, 39 (8), 12-17.

Green, S. B., \& Salkind, N. J. (2008). Using SPSS for windows and macintosh (Analyzing and Understanding Data-Fifth Edition). New Jersey: Pearson Prentice Hall.

Handelsman, M. M., Briggs, W. L., Sullivan, N., \& Towler, A. (2005). A measure of college student course engagement. The Journal of Educational Research, 98(3), 184192.

Hair, J.F., Black, W.C., Babin, B.J., \& Anderson, R.E. (2010). Multivariate Data Analysis. Seventh Edition. Prentice Hall, Upper Saddle River, New Jersey.

Herreid, C. F., \& Schiller, N. A. (2013). Case Studies and the Flipped Classroom. Journal of College Science Teaching, 42(5), 62-66.

Hung, H. (2015). Flipping the classroom for English language learners to foster active learning, Computer Assisted Language Learning, 28 (1), 81-96.

Hurley, K. S. (2014). A case study of learner and instructor perceptions of flipped course design and interactive learning environment, International Journal Social Media and Interactive Learning Environments, 2(4).

Kalaycı, Ş. (2005). SPSS uygulamalı çok değişkenli istatistik teknikleri. Ankara: Asil.

Kellinger, J. J. (2012). The flipside: Concerns about the "New literacies" paths educators might take. The Educational Forum, 76(4), 524-536.

Kordyban, R., \& Kinash, S. (2013). No more flying on auto pilot: The flipped classroom. Education Technology Solutions, 56, 54-56.

LaFee, S. (2013). Flipped learning. The Education Digest, November (2013), 13-18.

Millard, E. (2012). 5 reasons flipped classrooms work. University Business, 26-29.

Overmyer, G. R. (2014). The flipped classroom model for college algebra: Effects on student achievement. Unpublished PhD thesis. U.S.: Colorado State University. 
Özdamar, K. (2013). Paket programlar ile istatistiksel veri analizi. Eskişehir: Nisan.

Roehl, A., Reddy, S. L., \& Shannon, G. J. (2013). The flipped classroom: An opportunity to engage millennial students through active learning. Journal of Family and Consumer Sciences, 105 (2), 44.

Sarawagi, N. (2014). A flipped CS0 classroom: Applying Bloom's taxonomy to algorithmic thinking. Journal of Computing Sciences in Colleges. 29(6), 21-28.

Sever, M. (2014). Adapting Classroom Engagement Inventory into Turkish Culture. Education and Science, 39 (176), 171-182.

Skinner, E. A., Kinderman, T. A., \& Furrer, C. J. (2009). A motivational perspective on engagement and disaffection: Conceptualization and assessment of children's behavioral and emotional participation in academic activities in the classroom. Educational and Psychological Measurement, 69, 493-525.

Tabachnick, B. G., \& Fidell, L. S. (2001). Using multivariate statistics (4th Edition). New York: Allyn \& Bacon.

Tucker, B. (2012). The flipped classroom. Education Next, 12 (1), 82-83.

Wan, N. (2014). Flipping: The science classroom exploring merits, issues and pedagogy. Teaching Science. 60 (3), 16- 27.

Wang, Z., Bergin, C., \& Bergin, D. A. (2014). Measuring engagement in fourth to twelfth grade classrooms: The classroom engagement inventory. School Psychology Quarterly: The Official Journal of the Division of School Psychology, American Psychological Association, 29 (4), 517-35.

Yestrebsky, C. L. (2015). Flipping the classroom in a large chemistry class-research university environment. Procedia-Social and Behavioral Sciences, 191, 1113-1118. 